\title{
Article \\ Mechanical Performance of Gilsonite Modified Asphalt Mixture Containing Recycled Concrete Aggregate
}

\author{
Daniel Alberto Zuluaga-Astudillo ${ }^{1, * \mathbb{D}}$, Hugo Alexander Rondón-Quintana ${ }^{2} \mathbb{D}$ and Carlos Alfonso Zafra-Mejía ${ }^{2} \mathbb{D}$ \\ 1 Especialización en Diseño y Construcción de Vías y Aeropistas, Escuela de Ingenieros Militares, \\ Ejército Nacional de Colombia, Bogotá, DC 111611, Colombia \\ 2 Facultad del Medio Ambiente y Recursos Naturales, Universidad Distrital Francisco José de Caldas, \\ Bogotá, DC 110321, Colombia; harondonq@udistrital.edu.co (H.A.R.-Q.); \\ czafra@udistrital.edu.co (C.A.Z.-M.) \\ * Correspondence: daniel.zuluaga@esing.edu.co
}

Citation: Zuluaga-Astudillo, D.A.; Rondón-Quintana, H.A.; Zafra-Mejía, C.A. Mechanical Performance of Gilsonite Modified Asphalt Mixture Containing Recycled Concrete Aggregate. Appl. Sci. 2021, 11, 4409. https://doi.org/10.3390/app11104409

Academic Editors: Luís Picado Santos and João Crucho

Received: 10 April 2021

Accepted: 3 May 2021

Published: 13 May 2021

Publisher's Note: MDPI stays neutra with regard to jurisdictional claims in published maps and institutional affiliations.

Copyright: (c) 2021 by the authors. Licensee MDPI, Basel, Switzerland. This article is an open access article distributed under the terms and conditions of the Creative Commons Attribution (CC BY) license (https:// creativecommons.org/licenses/by/ $4.0 /)$

\begin{abstract}
Hot-mix asphalts exposed to hot weather and high traffic volumes can display rutting distress. A material that can be used to increase the stiffness of asphalt binders is gilsonite. On the other hand, from an environmental point of view, the virgin natural aggregates of asphalt mixtures can be replaced with recycled concrete aggregates. For these reasons, this study modified the asphalt binder with gilsonite by wet-process to improve rutting resistance, and replaced (by mass and volume) part of the coarse fraction of the aggregate with recycled concrete aggregate in two hot-mix asphalts with different gradations. Unlike other studies, a larger experimental phase was used here. Marshall, indirect tensile strength, resilient modulus, permanent deformation, fatigue resistance, and Cantabro tests were performed. An ANOVA test was carried out. If the replacement of the virgin aggregate by recycled concrete aggregates was made by volume, both materials (gilsonite and recycled concrete aggregate) could be used in hot-mix asphalts for thick-asphalt layers in high temperature climates and any level of traffic. The use of both materials in hot-mix asphalts is not recommended for thin-asphalt layers in low temperatures climates. It is not advisable to replace the aggregates by mass.
\end{abstract}

Keywords: hot-mix asphalt; modified asphalt binder; gilsonite; recycled concrete aggregate RCA

\section{Introduction}

\subsection{Gilsonite Background}

Gilsonite is a natural fossil resource that was discovered more than one century ago, hence, it has been broadly studied. It is a type of natural asphalt (generally solid) derived from petroleum, which has a predominantly dark brown color, and is found widely around the world. It is naturally produced through the penetration of oil or petroleum in rocks under combined actions of heat, pressure, oxidation, and microbe activity throughout millions of years [1]. It is a hard and brittle material [2], but it can easily be crushed into powder. It is also scientifically named uintaite [3-5]. This resinous hydrocarbon has been evaluated and used in different industrial processes [3,4,6,7]. Generally, it presents a carbon content superior to $70 \%$ and a low $\mathrm{H} / \mathrm{C}$ ratio, which indicates a high degree of molecular condensation. It contains a large quantity of $\mathrm{N}, \mathrm{O}$, and $\mathrm{S}$ elements in which there are existing functional polar groups and a high presence of metallic elements. Upon carrying out SARA (Saturates, Aromatics, Resins, Asphaltenes)-fractions, gilsonite presents a high content of asphaltenes [4,8-12]. It is a material that is highly compatible with conventional asphalt binders $[13,14]$. Gilsonite is soluble in aromatic and aliphatic solvents, as well as in petroleum derivates [4].

In pavements, gilsonite is a material used to modify the properties of asphalt binders. In particular, it is used to increase the stiffness and thermal susceptibility $[5,15,16]$. Therefore, it helps to increase the resistance of hot-mix-asphalts (HMA) to the phenomenon 
of rutting in high temperature climates [1,17-29], increasing the Marshall stability and stiffness under a cyclic load (e.g., resilient modulus and dynamic modulus) and resistance to permanent deformations. There have also been reports of improvements regarding moisture damage resistance $[1,2,5,16,24,28,30]$ and indirect tension resistance $[5,31]$. However, in low temperature climates, this may generate problems associated with thermal and fatigue-induced cracking [1,32-35]. Because of this, several studies have combined gilsonite with other conventional polymeric additives (e.g., styrene-butadiene-styrene (SBS), styrene butadiene rubber (SBR), and crumb rubber) in order to modify asphalt binders $[1,31,36,37]$. Additionally, in high addition percentages, it can considerably increase the viscosity of the asphalt binder, negatively affecting mix temperatures (workability) and compaction, increasing energy consumption and environmental pollution [1,2]. Despite the above, if the gilsonite dose is controlled up to a certain point, it may not exert a considerably negative influence upon the mentioned aspects [3,38]. On the other hand, in comparison with other modifiers, gilsonite offers advantages in terms of lower costs and increased ease of use $[1,5,21,24,32,39]$.

\subsection{Recycled Concrete Aggregate Background}

During the construction process of roadway projects, large quantities of natural origin aggregates (NA) are consumed. This negatively impacts the environment. According to the authors of [39], roadway construction produces approximately $28 \%$ of the world's energy consumption and $22 \%$ of global $\mathrm{CO}_{2}$ emissions. A way of reducing these impacts (reduction of the carbon footprint in the construction industry, conservation of natural resources, and reduction of hazardous emissions, among others) is replacing NAs with recycled concrete aggregates (RCAs). The latter is obtained from construction and demolition (C\&D) waste (CDW), which has been increasing because of growth in the construction industry [40,41]. The authors of [42], referring to other researchers, mention that an average between $30 \%$ and $40 \%$ of the total solid waste material comes from C\&D activities. Additionally, they mention that RCAs represent between $50 \%$ and $70 \%$ (in weight) of the total CDW. For these reasons, several studies have been carried throughout the world to evaluate the use of RCAs as a substitute for NAs. Some factors that limit the use of RCAs are (i) the need for using large spaces for their storage; (ii) experience in residue recycling operations, supervisors, and trained personnel are all required; (iii) it requires knowledge about waste material markets; and (iv) it requires a high degree of awareness regarding environmental and safety regulations [43].

The broadly identified problem in most RCA studies is that these are materials with a high degree of heterogeneousness, which present greater absorption and lower mechanical resistances than those of NAs [44-49]. This is mainly because of the adhered mortar attached to the RCA particles [50-52]. Additionally, RCAs present impurities such as bricks, roof tiles, ceramic, and organic materials, among others. Because of this, most part studies have focused on evaluating the behavior of RCAs as a substitute for NAs in the lower layers of pavement (e.g., subgrade, subbase, and base), which are exposed to less of the pressures produced by traffic [53]. However, the amount of RCA produced in the world already surpasses its common use (even in its use in pavement base and subbase), and therefore there is an existing need to broaden its use in asphalt mixes [47]. Additionally, differently to the use of RCAs in bases, subbases, or subgrades, in the context of asphalt mixes, there is an absence of the problem regarding the possible generation of lixiviates [54]. Despite the identified problems, some authors have mentioned that RCAs present particles with ideal shapes (fractured faces with low flattening and elongation indexes) that can help to generate a compact granular skeleton with good intergranular friction [55]. Furthermore, their greater porosity in comparison with NAs can help to improve adhesion to asphalt binders. RCAs have not only been experimentally characterized, but the complex failure processes of these materials have been simulated using the discrete-element method (DEM) [56].

Regarding asphalt mixes, studies have mainly focused on substituting (generally by mass) NA with RCA in different proportions (even replacing the totality of the aggregate), 
and then measuring the changes that took place in the mixes, as well as their mechanical resistance. The literature is ambiguous regarding drawing conclusions related to the obtained results. While some studies have reported that the evaluated properties improve, others have concluded the opposite $[48,57,58]$. Furthermore, there is a great disparity about the recommendations regarding the replacement levels of NAs for RCAs in asphalt mixes [58]. Likewise, the behavior of mixes may change depending on the source from where the RCA was obtained [48]. Despite the above, most studies conclude the following: (i) mixes with RCAs show satisfactory results when they are placed in the asphalt layers of roadways with a low traffic volume, and (ii) it is necessary to use greater asphalt contents as the quantity of RCA used is greater [59]. Additionally, several studies have concluded that asphalt mixes that use RCAs comply with the design criteria of several countries, which enhances its use [60-65]. To reduce asphalt consumption and improve the properties of RCAs, some studies have conducted pre-treatment for these materials. For example, some studies have covered RCA particles with a slag cement paste [66], bitumen emulsion [43,67], silane-based water repellent agents [68], or a carbonation technique [69]. Others have applied combined coating techniques with additives such as Tite-BE and heating [46], while others have attempted to mechanically eliminate the adhered mortar [70]. States of knowledge regarding the topic of RCA pre-treatment can be consulted in the literature [71,72]. The authors of [72] mention that RCA pre-treatment methods are mainly classified into the following two types: the elimination of adhered mortar and reinforcement of adhered mortar. According to the authors of [71], it is much more effective and efficient from an energy standpoint to coat RCAs that to attempt to eliminate the adhered mortar.

\subsection{Problem Statement and Objective}

In Colombia, average annual temperatures above $24{ }^{\circ} \mathrm{C}$ cover almost $70 \%$ of the total area in the country. Moisture, in terms of average annual relative humidity, is above $60 \%$ [73]. Because of this, within a large part of the Colombian territory, the most common pavement distress type is rutting. This motivated the use of gilsonite in this study, with the purpose of stiffening the asphalt binder, thus attempting to increase rutting resistance for the two types of HMAs that are mostly used throughout Colombia (named MDC-19 and MDC-25, according to the authors of [74]). Additionally, for the case of Colombia, the use of RCAs as replacements for NAs in HMAs could be an interesting alternative, taking into account that projections for 2019-2024 indicate the use of 75 million tons of NAs for the construction of roadways [75]. In addition, a great portion of the national roadway network is comprised of unpaved roadways [76].

Few studies have combined the effects of modifying the asphalt binder with gilsonite and using RCAs as replacement for NAs in HMAs. The authors of $[77,78]$ conducted limited experimental studies combining both effects, but in porous mixes. The authors of [79] conducted a study on an HMA; however, the scope of the experimental phase was also limited (only conducted using Marshall, indirect tensile strength (ITS), and Cantabro tests; used one gradation; and the substitution of NA with RCA was carried out according to mass). In addition, few studies have replaced the NA with RCA dosing according to volume; despite this, several researchers recommend doing so because it is more appropriate for these types of porous materials $[59,80]$. This is because RCA particles generally have a lower specific gravity than NAs, and when replacing according to mass, a greater amount of RCA particles that are to be coated with asphalt are introduced into the mix [81].

Given all of the above reasons, in contrast to other studies conducted on the topic, this study evaluated the combined effects of modifying asphalt cement (AC) with gilsonite through a wet process, and replaced (dosing by mass and by volume) part of the coarse fraction of NA with RCA in mixes of MDC-19 and MDC-25. Marshall, resilient modulus, and permanent deformation tests were carried out in order to evaluate the rutting resistance. Additionally, ITS, fatigue, and Cantabro tests were carried out to evaluate the durability related aspects. In order to know if changes in properties were statistically significant, 
an ANOVA test was carried out with test $\mathrm{F}$ and a reliability level of $95 \%$. The values of $\mathrm{F}>\mathrm{F}_{0.05}$ represented statistically significant variations.

\section{Materials and Methods}

\subsection{Materials}

In this research, an AC 60-70 (penetration grade in $0.1 \mathrm{~mm}$ ) was used as asphalt binder, whose properties are shown on Table 1.

Table 1. General properties of asphalt cement (AC) 60-70.

\begin{tabular}{lccc}
\hline \multicolumn{1}{c}{ Test } & Method & Unit & Value \\
\hline & Tests on the original AC & \\
\hline Penetration $\left(25^{\circ} \mathrm{C}, 100 \mathrm{~g}, 5 \mathrm{~s}\right)$ & ASTM D-5 & $0.1 \mathrm{~mm}$ & 63.8 \\
Softening point & ASTM D-36-95 & ${ }^{\circ} \mathrm{C}$ & 51.7 \\
Absolut viscosity $\left(60^{\circ} \mathrm{C}\right)$ & ASTM D-4402 & Poises & 1690 \\
Specific gravity & AASHTO T 228-04 & - & 1.012 \\
Viscosity to $135^{\circ} \mathrm{C}$ & AASHTO T-316 & Pa-s & 0.35 \\
\hline \multicolumn{4}{c}{ Tests on the residue of AC after the RTFOT (Rolling Thin Film Oven Test) } \\
\hline Mass loss & ASTM D-2872 & $\%$ & 0.57 \\
Penetration $\left(25^{\circ} \mathrm{C}, 100 \mathrm{~g}, 5 \mathrm{~s}\right)$, in & ASTM D-5 & $\%$ & 70 \\
percentage of the original penetration & ASTM D-36-95 & ${ }^{\circ} \mathrm{C}$ & 5 \\
Increase on the softening point &
\end{tabular}

Gilsonite (Figure 1a) has a specific gravity of $1.03 \mathrm{~g} / \mathrm{cm}^{3}$. Its penetration measured at $25{ }^{\circ} \mathrm{C}$, according to the ASTM D-5 specification, is $0 \mathrm{~mm} / 10$ and its softening point, measured according to ASTM D-36, is $92^{\circ} \mathrm{C}$. Its particles pass through a sieve $40(0.425 \mathrm{~mm})$. The properties of NA aggregates (Figure 1b) and RCA (Figure 1c) are shown in Table 2. The specific gravity and abrasion wear resistance of NA is greater in comparison with RCA. This is mainly because of the presence of adhered mortar, the greater porosity, and absorption of the RCA, as described in the RCA background. It is worth highlighting that RCA particles present a better geometry (greater percentages of fractured faces and less percentages of elongated and flattened particles).

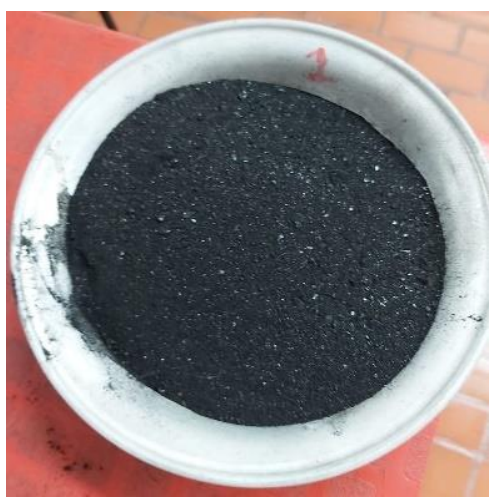

(a)

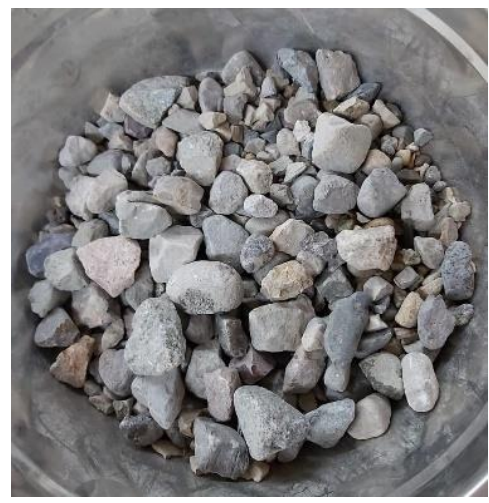

(b)

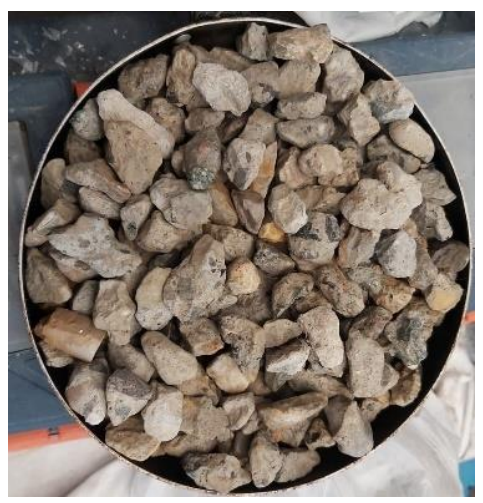

(c)

Figure 1. Materials: (a) gilsonite (G); (b) natural origin aggregates (NA); (c) recycled concrete aggregate (RCA). 
Table 2. Properties of NA and RCA particles.

\begin{tabular}{lccc}
\hline \multicolumn{1}{c}{ Test } & Method & NA & RCA \\
\hline Specific gravity/absorption-coarse & AASHTO T 84 & $2.65 / 1.8 \%$ & $2.52 / 4.9 \%$ \\
Specific gravity/absorption-fine & AASHTO T 85 & $2.53 / 1.5 \%$ & $2.48 / 5.2 \%$ \\
Los Angeles Machine, 500 & AASHTO T 96 & $22.7 \%$ & $31.1 \%$ \\
revolutions & AASHTO T327 & $21.1 \%$ & $29.0 \%$ \\
Micro-deval & ASTM D 5821 & $87.6 \%$ & $97.2 \%$ \\
Fractured particles: 1 face & ASTM D 4318 & No plastic & No plastic \\
Plasticity index & NLT 354 & $6.5 \%$ & $3.0 \%$ \\
Flattening index & & $8.2 \%$ & $2.2 \%$ \\
Elongation index & & & \\
\hline
\end{tabular}

\subsection{Modification of AC $60-70$}

Gilsonite was added to the AC 60-70 through a wet process in a proportion of $10 \%$ with relation to the asphalt binder's mass. The temperature and time to mix both materials (AC 60-70 and gilsonite) was $160^{\circ} \mathrm{C}$ and $10 \mathrm{~min}$, respectively. This mix was performed using high shear mixer equipment at $3000 \mathrm{rpm}$. The addition percentage, temperature, and mix time were chosen based on the results of previous studies [22,28,82]. The modified AC was named $A C / G / 10 \%$. The properties of $A C / G / 10 \%$ are presented in Table 3. It was observed that gilsonite notably increased the asphalt binder stiffness (reduces penetration, increases softening points and viscosity). This increase in stiffness was mainly due to the high content of asphaltenes in gilsonite [4,10-12], as well as its lower penetration and higher viscosity and softening point compared with AC 60-70 asphalt binder.

Table 3. Properties of AC/G/10\%.

\begin{tabular}{lccc}
\hline \multicolumn{1}{c}{ Test } & Method & Unit & Value \\
\hline \multicolumn{4}{c}{ Tests on the original AC } \\
\hline Penetration $\left(25^{\circ} \mathrm{C}, 100 \mathrm{~g}, 5 \mathrm{~s}\right)$ & ASTM D-5 & $0.1 \mathrm{~mm}$ & 42.0 \\
Softening point & ASTM D-36-95 & ${ }^{\circ} \mathrm{C}$ & 75.6 \\
Specific gravity & AASHTO T 228-04 & - & 1.014 \\
Viscosity to $135^{\circ} \mathrm{C}$ & AASHTO T-316 & Pa-s & 1.02 \\
\hline \multicolumn{4}{l}{ Tests on the residue of AC after the RTFOT } \\
\hline Aass loss & ASTM D-2872 & $\%$ & 0.44 \\
\hline
\end{tabular}

\subsection{Mix Design Procedure}

In this research, six types of mixes were designed and tested, which are described as follows:

- The MDC-19 and MDC-25 mixes were the control. These used AC 60-70 as a binder and $100 \%$ of their aggregates were NA. The gradation of these mixes is presented in Figure 2.

0 The MDC-19-M and MDC-19-V mixes had the gradation of the MDC-19 mix; however, they used $\mathrm{AC} / \mathrm{G} / 10 \%$ as a binder and replaced $21 \%$ (particles retained in sieve $3 / 8^{\prime \prime}$ or $9.5 \mathrm{~mm}$ ) of the NA with RCA. M or V indicate that the replacement was carried out by mass or volume, respectively.

0 The MDC-25-M and MDC-25-V mixes had the gradation of the MDC-25 mix; however, they used AC/G/10\% as a binder and replaced $24 \%$ (particles retained in sieve $1 / 2$ " or $12.5 \mathrm{~mm}$ ) of the NA aggregate with RCA.

Considering that the gradation of RCA presented more than $90 \%$ of the material that was retained in a $3 / 8^{\prime \prime}$ sieve $(9.5 \mathrm{~mm})$, a replacement of $21 \%$ and $24 \%$ of the mass of NA with RCA was chosen for MDC-19-M and MDC-25-M, respectively. In other words, harnessing RCA was greater when replacing the coarse fraction of NA. Replacing this with particles of a smaller size would increase the costs, entailing an industrial process. 
Additionally, particle sizes corresponding to the superior sieves were chosen on each mix to carry out the replacements $\left(1 / 2^{\prime \prime}+3 / 8^{\prime \prime}\right.$ on MDC-19 and 3/4" $+1 / 2^{\prime \prime}$ on MDC-25). In order to make the replacements according to volume for mixes MDC-19-V and MDC-25-V, the specific gravities of both aggregates (NA and RCA) were taken into consideration, and the guidelines recommended by the authors of [80] were followed.

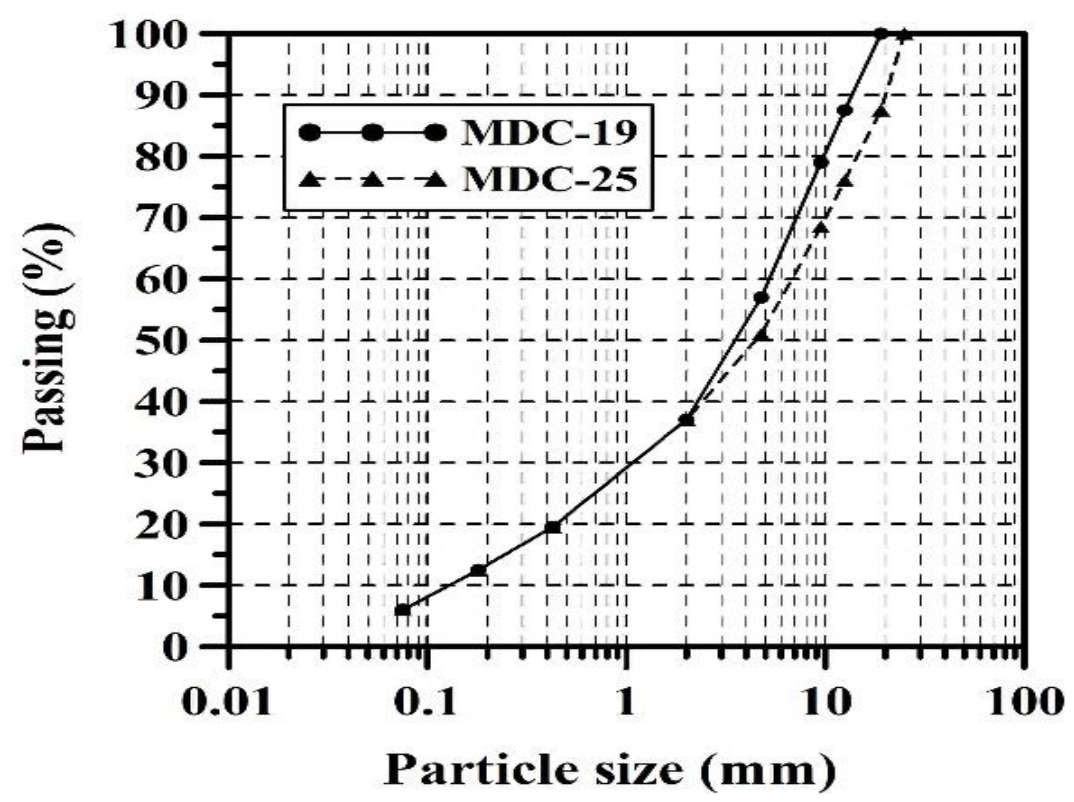

Figure 2. Gradation of the MDC-19 and MDC-25 mixes.

The method used to design and obtain the optimal asphalt content (OAC) of mixes was the Marshall method. For this reason, the manufactured samples were Marshall type (cylindric samples compacted at 75 blows per face, with an approximate mass of $1200 \mathrm{~g}$, and with approximate dimensions of $63.5 \mathrm{~mm}$ in diameter and $101.6 \mathrm{~mm}$ in height). Additionally, the recommendations of the AASHTO T-245 general guidelines were followed, and all mixes were manufactured under short-term oven aging (STOA) conditions following the protocols recommended by AASHTO R30 (before compacting samples, these were heated in a loose state for $2 \mathrm{~h}$ inside a conventional oven at $135^{\circ} \mathrm{C}$ ).

The compaction and mix temperature for the control mixes (MDC-19 and MDC-25) were $150{ }^{\circ} \mathrm{C}$ and $145{ }^{\circ} \mathrm{C}$, respectively. These temperatures were chosen based on the viscosity vs. temperature curve obtained for AC 60-70 (viscosity of $170 \pm 20 \mathrm{MPa}$-s for the mix temperature and $280 \pm 30 \mathrm{MPa}$-s for compaction). For the other mixes, which used $\mathrm{AC} / \mathrm{G} / 10 \%$, said temperatures were $165^{\circ} \mathrm{C}$ and $160{ }^{\circ} \mathrm{C}$, respectively. These last temperatures were not chosen based on viscosity curves vs. temperature, given that for the case of modified asphalt binders, this criterion is not realistic $[22,83,84]$. In this study's case, viscosity curves vs. temperature for $\mathrm{AC} / \mathrm{G} / 10 \%$ indicated the need for increasing both temperatures by more than $30^{\circ} \mathrm{C}$. For this reason, an increase of $15^{\circ} \mathrm{C}$ was chosen to avoid aging and degradation of the modified asphalt binder's properties. Likewise, it was selected through trial and error, considering that the aggregate's particles were easily coated with the modified asphalt binder.

Regarding the mix design, four asphalt percentages per mix were used. Likewise, three samples per asphalt percentage were manufactured to obtain the volumetric and resistance parameters for the Marshall test. Stability and flow were obtained from a Marshall compression machine by applying a loading rate of $50.8 \mathrm{~mm} /$ minute (sample temperature was $60^{\circ} \mathrm{C}$ ). 


\subsection{Resilient Modulus, Permanent Deformation, and Fatigue Resistance}

Using a Nottingham Asphalt Tester (NAT) machine, the stress-strain relationship of each asphalt mix was depicted trough resilient modulus (RM) tests (ASTM D4123). The "half-sine" load type was applied under frequencies of $2.5 \mathrm{~Hz}, 5.0 \mathrm{~Hz}$, and $10 \mathrm{~Hz}$. The test temperatures were 10,20 , and $30^{\circ} \mathrm{C}$. Each RM was determined based on the average of results obtained on the three Marshall samples using the OAC.

Permanent deformation resistance tests were carried out using the NAT machine and following the UNE-EN 12697-25 standard. The test temperature was $40^{\circ} \mathrm{C}$. Initially, 600 cycles of preload (10 kPa) were applied for $20 \mathrm{~min}$ per sample. Posteriorly, 3600 load cycles under a stress of $100 \mathrm{kPa}$ were applied. Vertical displacement was measured by using LVDTs (linear variable differential transformers). The load cycles were a square wave type with a frequency of $0.5 \mathrm{~Hz}$. (1 s of load application and $1 \mathrm{~s}$ of rest per cycle). Each permanent deformation curve was determined by averaging the results obtained on the three samples.

Fatigue resistance was measured using the NAT machine (UNE-EN 12697-24). Controlledstress was the indirect tensile load mode. The load frequency and test temperature were $10 \mathrm{~Hz}$ and $20^{\circ} \mathrm{C}$, respectively. Sample total rupture was the criterion used to obtain the failure number of cycles $\left(N_{f}\right)$. Nine Marshall samples for each asphalt mix were tested to obtain each fatigue curve.

\subsection{Indirect Tensile Strength (ITS) and Cantabro Tests}

ITS tests were carried out on the mixes manufactured with the OAC obtained by design. In order to conduct this test, guidelines established in the AASHTO T 283 specification were followed. Three conditioned Marshall samples (C) were tested by type of asphalt mix and for another three under unconditioned samples (U). The air voids content of each sample ranged between $7 \pm 0.5 \%$. Each sample was loaded radially at a speed of $50 \mathrm{~mm} / \mathrm{min}$, using a Marshall compression machine. The maximum load at fracture was measured at a temperature of $25^{\circ} \mathrm{C}$. The indirect tensile strength (ITS) under C (ITS-C) and $\mathrm{U}$ (ITS-U) conditions were obtained. Both parameters were calculated in percentage, using a tensile strength ratio $($ TSR $)=($ ITSC $/$ ITSU $) \times 100$.

The Cantabro test is broadly used to characterized open-graded type asphalt mixes. However, during the latest years, it has been used to provide information regarding aspects associated with durability in dense-graded type asphalt mixes $[85,86]$. The percent of weight loss (Cantabro loss (CL)) was calculated by applying 500 cycles in the "Los Angeles machine" (without steel spheres). Three samples were tested for the asphalt mix. The test temperature was a room laboratory temperature of $20^{\circ} \mathrm{C}$.

\section{Results and Discussion}

\subsection{Marshall Test}

The Marshall test results are shown in Figures 3 and 4. The OAC of the MDC-19, MDC19-M, MDC-19-V, MDC-25, MDC-25-M, and MDC-25-V mixes is of 5.5\%, 6.0\%, 5.5\%, 5.0\%, $5.5 \%$, and $5.0 \%$, respectively (see Table 4). For the case of the MDC-19, MDC-19-V, MDC-25, and MDC-25- $\mathrm{V}$ mixes, the design criteria were fulfilled for any traffic level according to the authors of [74], while for the MDC-19-M and MDC-25-M mixes, these were only fulfilled for low traffic levels $\left(80 \mathrm{kN}\right.$ equivalent single axle load (ESAL) $\left.<5 \times 10^{5}\right)$. S, F, Va, VFA and VMA are stability, flow, air void content, voids filled with asphalt and voids in mineral aggregate, respectively.

The greater absorption of RCA particles and the greater viscosity and stiffness of the modified asphalt binder caused the mixes to undergo increases in Va and reductions in VFA. Despite the above, these volumetric changes were minor when the replacement of NA with RCA was carried out by volume. This occurred because of the entry of a lower quantity of RCA particles when replaced by volume. According to the ANOVA test, the mass and volume replacements of NA with RCA generated statistically significant volumetric changes. Additionally, based on the ANOVA test, a notable increase was observed in 
the $S$ and S/F parameters when the replacement was carried out by volume and when modified asphalt binder was used. This increase in resistance was mainly due to the greater stiffness of the modified asphalt binder. Contrary to the above, the replacement of NA with RCA according to mass produced mixes with a level of resistance under a monotonic load in the Marshall test that tended to be lower in comparison with the control mix. During the monotonic compression in the Marshall press, MDC-19-M and MDC-25-M mixes were more prone to failure because of the greater presence of mortar adhered to the RCA particles, and because of their greater porosity (higher Va and lower VFA).

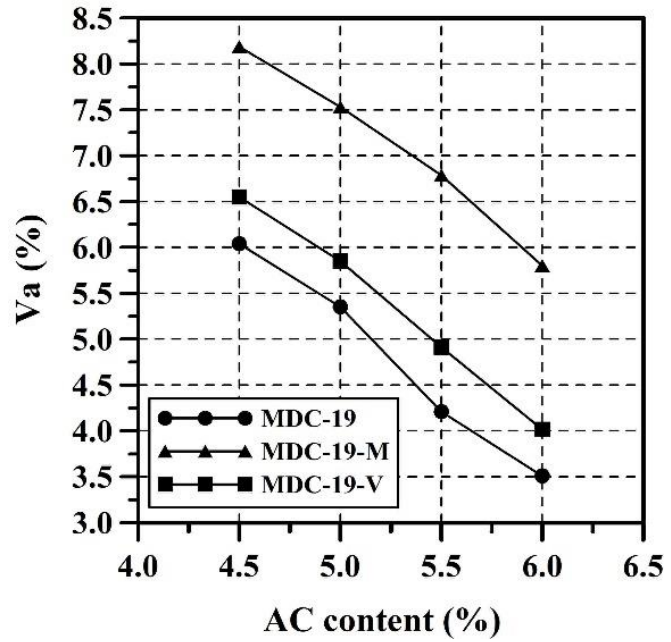

(a)

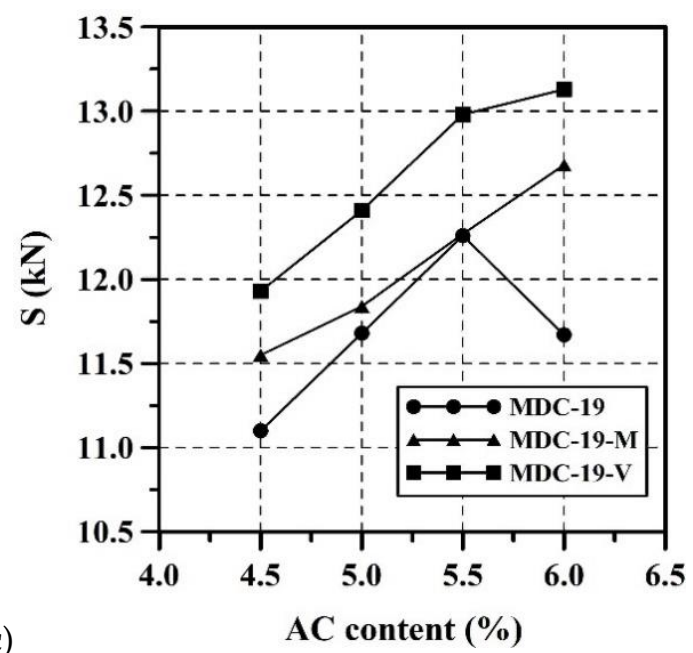

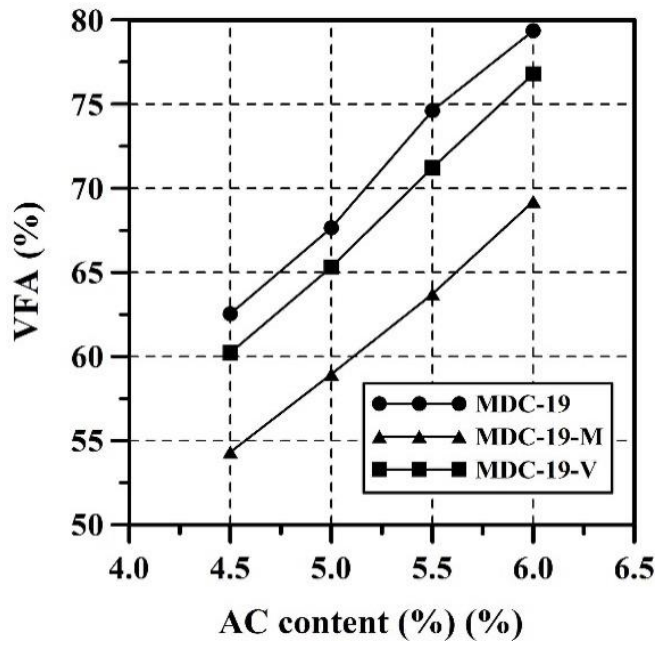

(b)

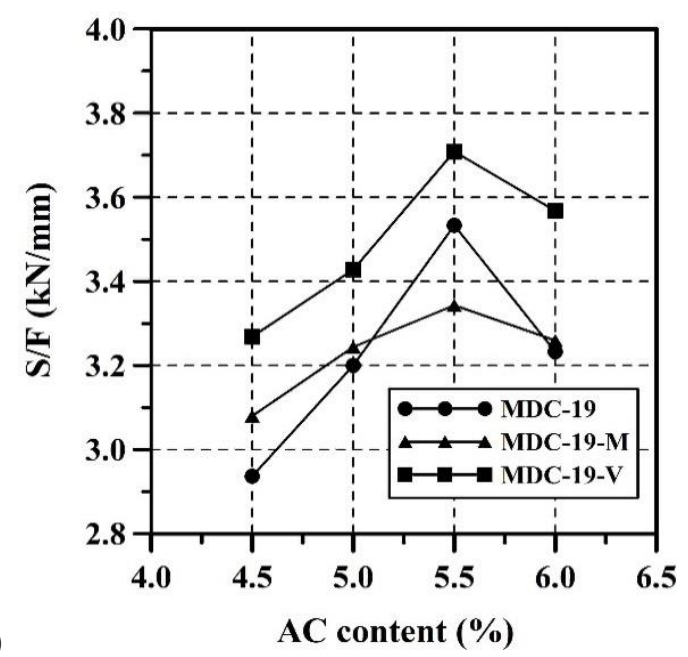

Figure 3. Marshall test results of MDC-19, MDC-19-M, and MDC-19-V: (a) Va content; (b) VFA content; (c) stability-S; (d) S/F ratio.

Table 4. Values of Marshall test results in OAC.

\begin{tabular}{|c|c|c|c|c|c|c|}
\hline Parameter & $\begin{array}{c}\text { MDC-19 } \\
\text { OAC }=5.5 \%\end{array}$ & $\begin{array}{l}\text { MDC-19-M } \\
\text { OAC }=6.0 \%\end{array}$ & $\begin{array}{l}\text { MDC-19-V } \\
\text { OAC }=5.5 \%\end{array}$ & $\begin{array}{c}\text { MDC-25 } \\
\text { OAC }=5.0 \%\end{array}$ & $\begin{array}{l}\text { MDC-25-M } \\
\text { OAC }=5.5 \%\end{array}$ & $\begin{array}{l}\text { MDC-25-V } \\
\text { OAC }=5.0 \%\end{array}$ \\
\hline $\mathrm{S}(\mathrm{kN})$ & 12.3 & 12.7 & 13.0 & 12.5 & 12.7 & 13.1 \\
\hline $\mathrm{F}(\mathrm{mm})$ & 3.47 & 3.89 & 3.50 & 3.44 & 3.78 & 3.61 \\
\hline $\mathrm{S} / \mathrm{F}(\mathrm{kN} / \mathrm{mm})$ & 3.53 & 3.26 & 3.71 & 3.65 & 3.35 & 3.64 \\
\hline Va $(\%)$ & 4.2 & 5.8 & 4.9 & 5.4 & 6.2 & 5.9 \\
\hline VMA (\%) & 16.6 & 18.9 & 17.1 & 16.6 & 18.2 & 17.0 \\
\hline VFA $(\%)$ & 74.6 & 69.2 & 71.2 & 67.7 & 65.9 & 65.0 \\
\hline
\end{tabular}



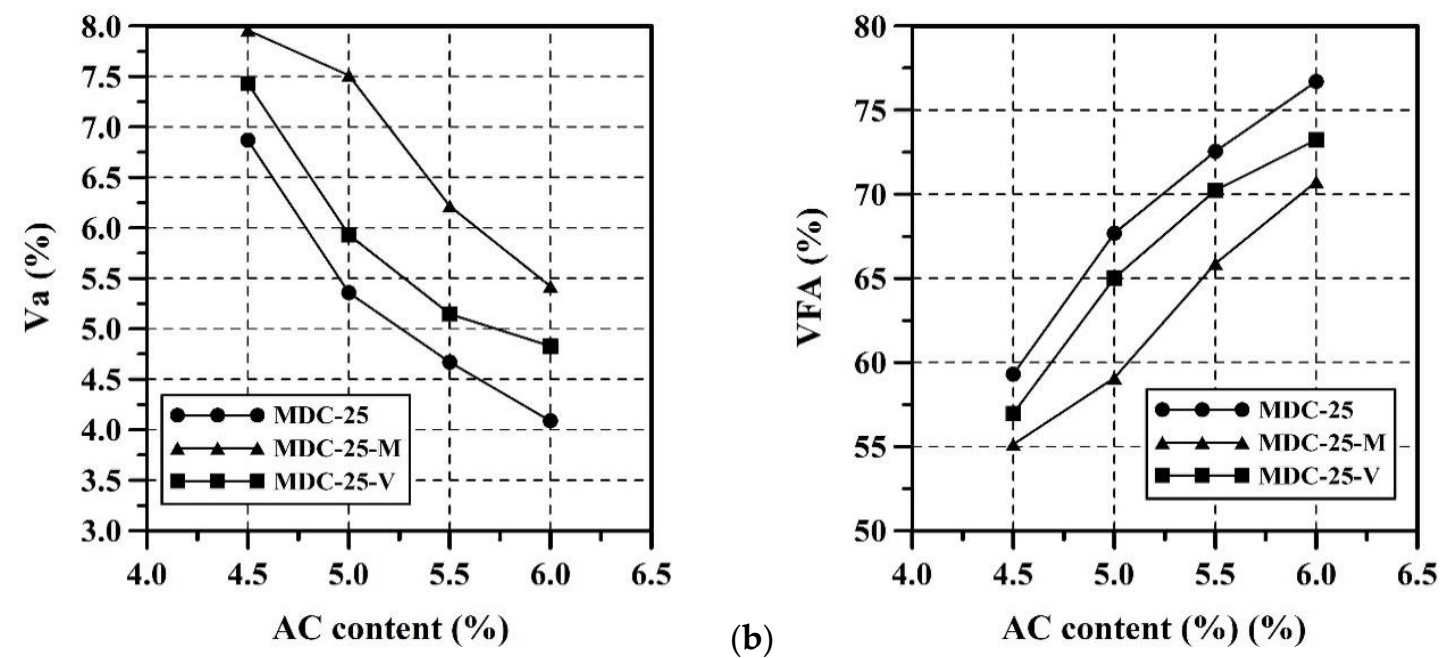

(a)

(b)
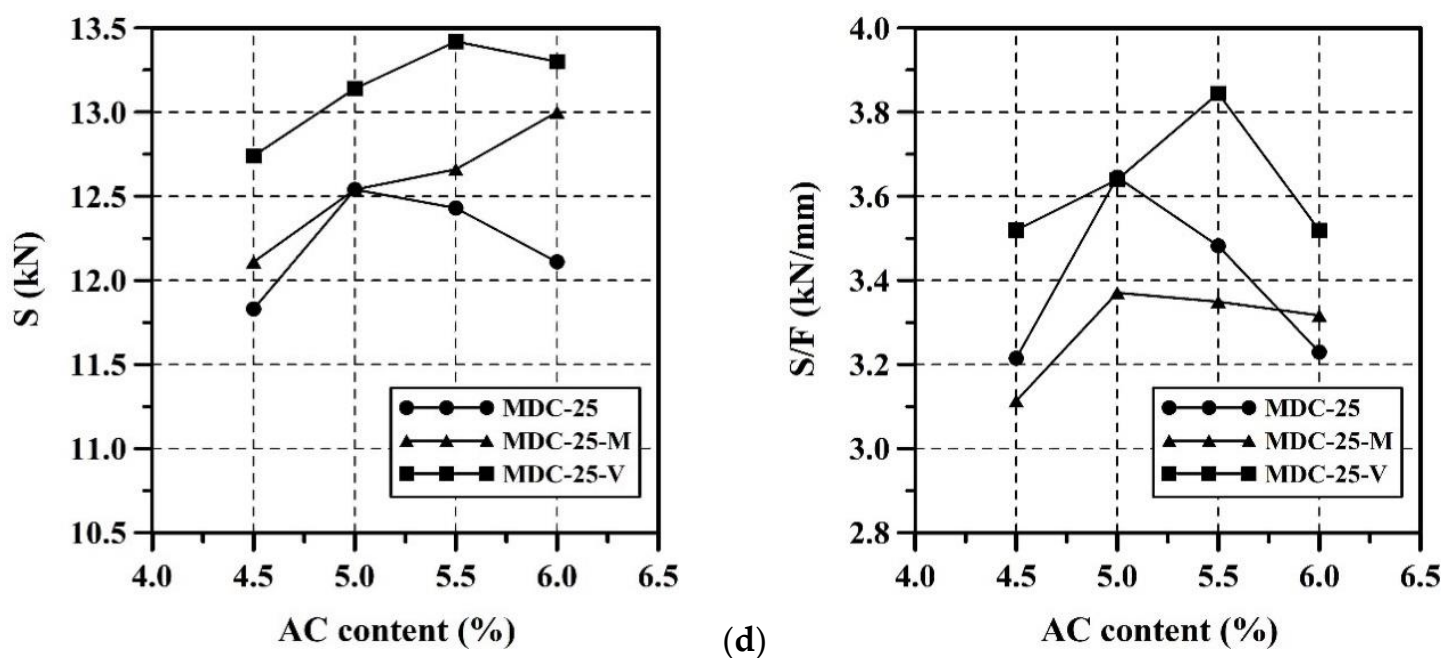

Figure 4. Marshall test results of MDC-25, MDC-25-M, and MDC-25-V: (a) Va content; (b) VFA content; (c) stability-S; (d) S/F ratio.

\subsection{Resilient Modulus (RM) and Permanent Deformation Tests}

The results of the RM tests are shown in Figures 5 and 6. According to the ANOVA test, the mixes that replaced the NA with RCA according to volume and used modified asphalt binder significantly increased their RM with relation to the control mixes. These increases were greater as the test temperature increased. The increase in RM was mainly due to the increase in stiffness of the modified asphalt binder.

On the other hand, when the replacement of the NA with RCA was carried out according to mass, the mixes that utilized modified asphalt tended to slightly increase the RM (except for MDC-19-M in $10{ }^{\circ} \mathrm{C}$ ); however, said increases were not statistically significant according to the ANOVA test. On one hand, the modified asphalt binder helped to increase the RM in these mixes, but their greater porosity (greater Va and lower VFA), greater quantity of RCA particles to be coated with asphalt binder, and lower mechanical performance of RCA particles compared with NA, contributed to reducing it.

The permanent deformation test results are shown in Figure 7. It is observable that mixes with RCA and modified asphalt underwent a greater permanent deformation resistance in comparison with the control mixes. The above is consistent with the increase in stiffness of the modified asphalt binder. The replacement of NA with RCA according to volume helped to increase resistance to the phenomenon of rutting even more so, which was coherent with the increase of RM in these mixes. For the case of mixes where replacement was carried out according to mass, it is possible that the increase of number of contacts between particles could have helped to increase the permanent deformation resistance. 

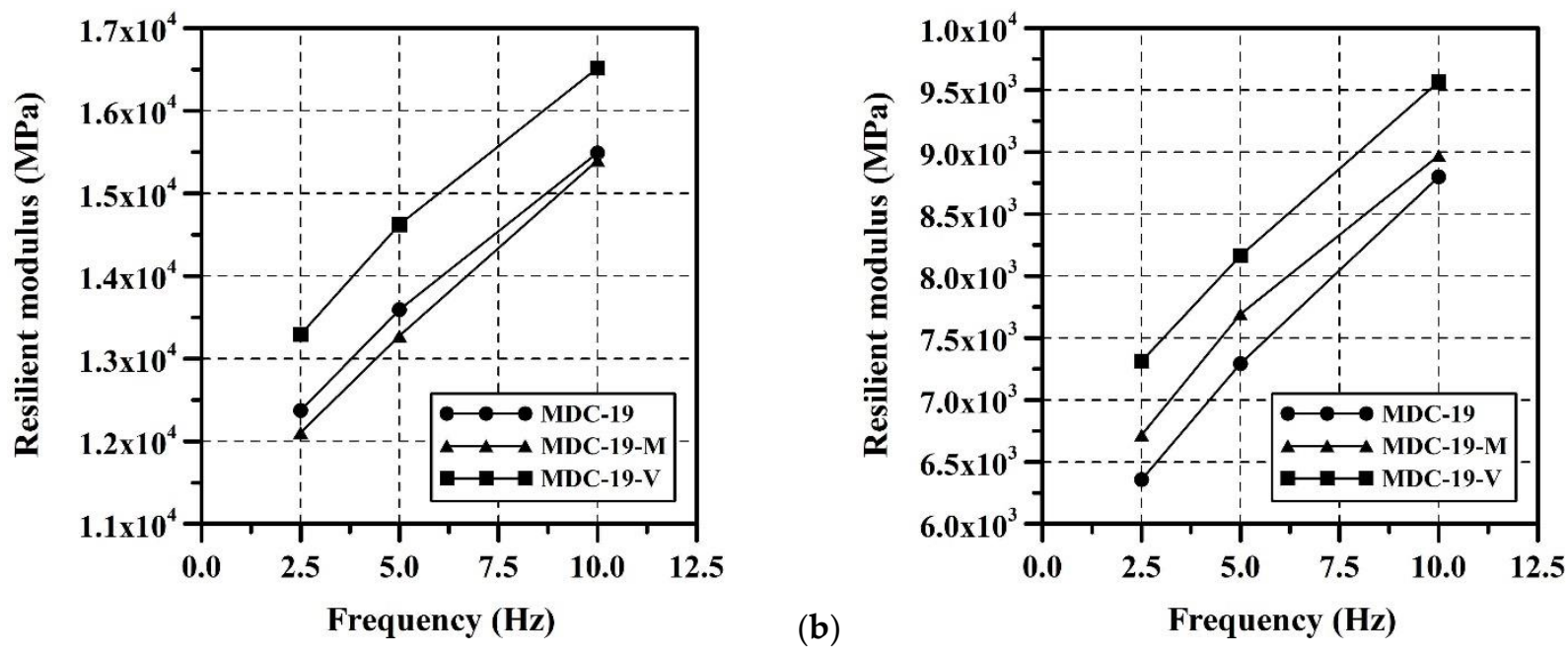

(a)

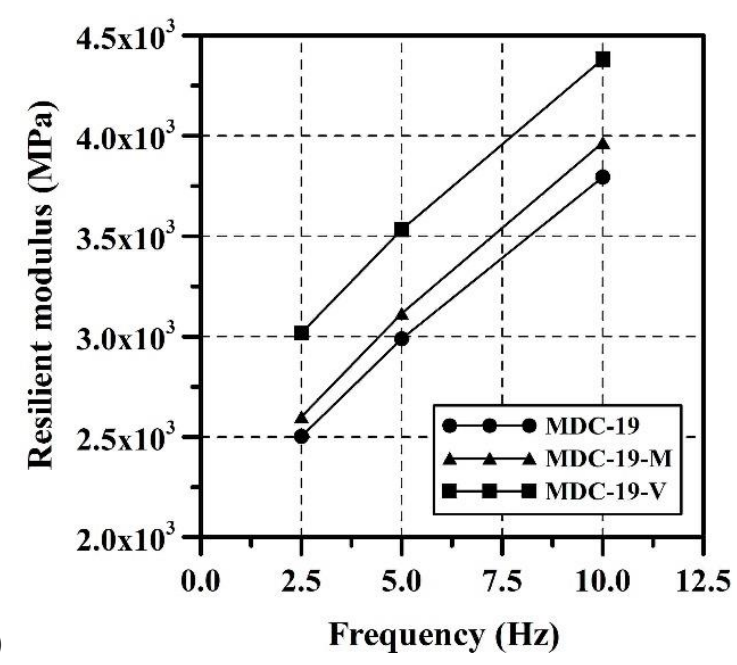

Figure 5. Resilient modulus MDC-19, MDC-19-M, and MDC-19-V: (a) $10^{\circ} \mathrm{C}$; (b) $20^{\circ} \mathrm{C}$; (c) $30^{\circ} \mathrm{C}$.
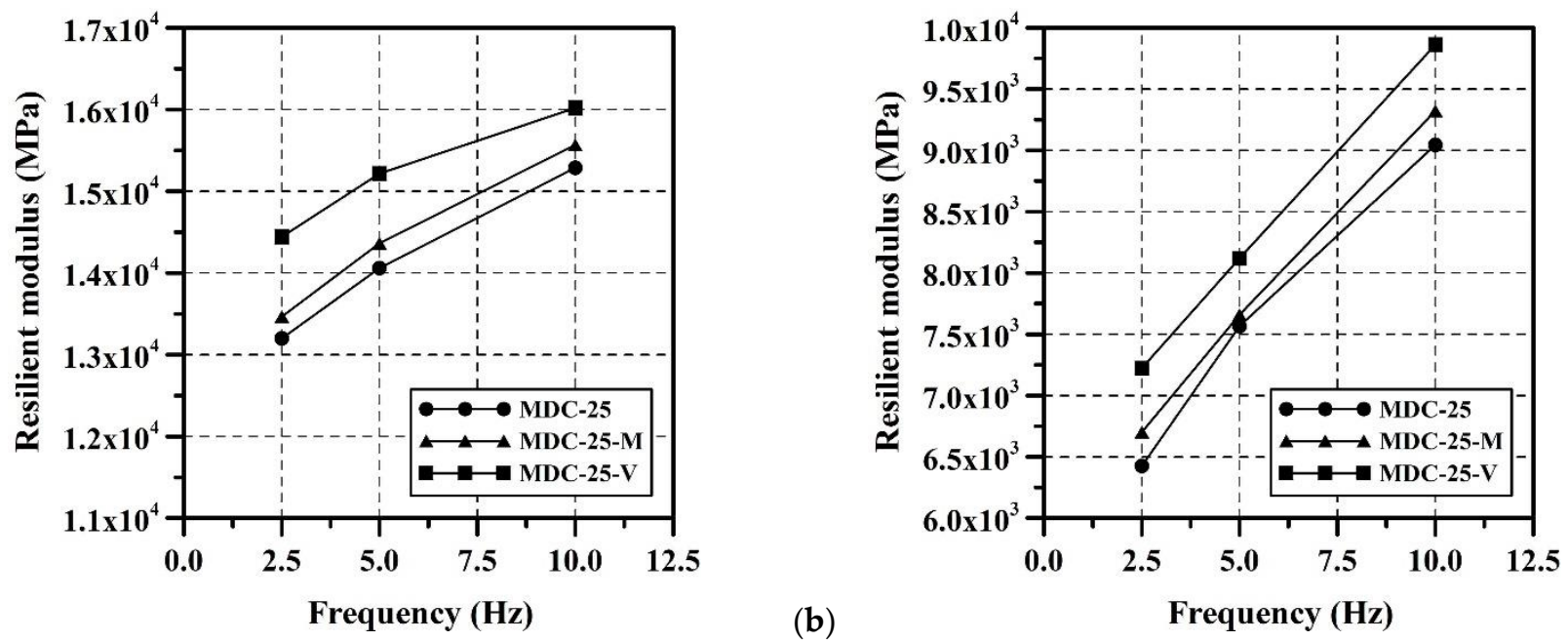

Figure 6. Cont. 


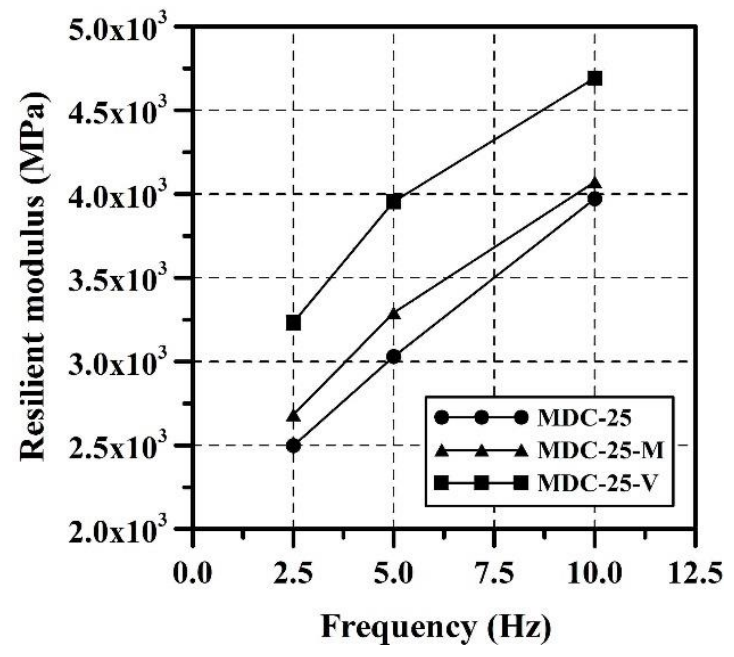

Figure 6. Resilient modulus MDC-25, MDC-25-M, and MDC-25-V: (a) $10^{\circ} \mathrm{C}$; (b) $20^{\circ} \mathrm{C}$; (c) $30^{\circ} \mathrm{C}$.

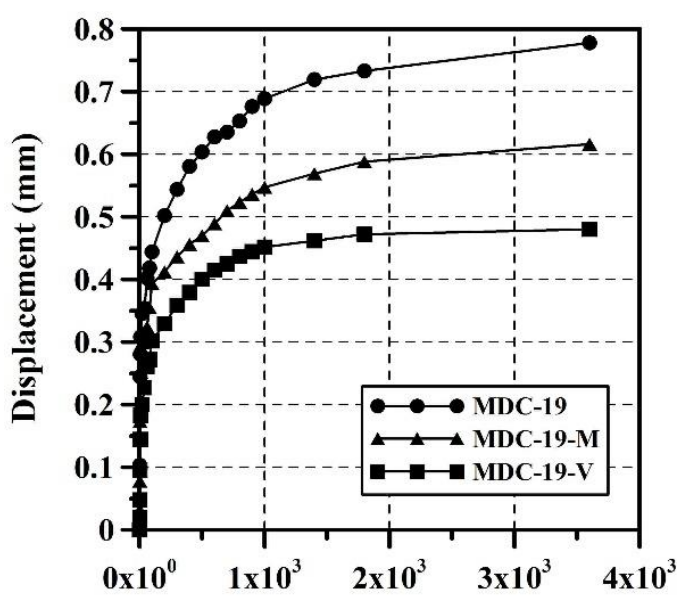

(a)

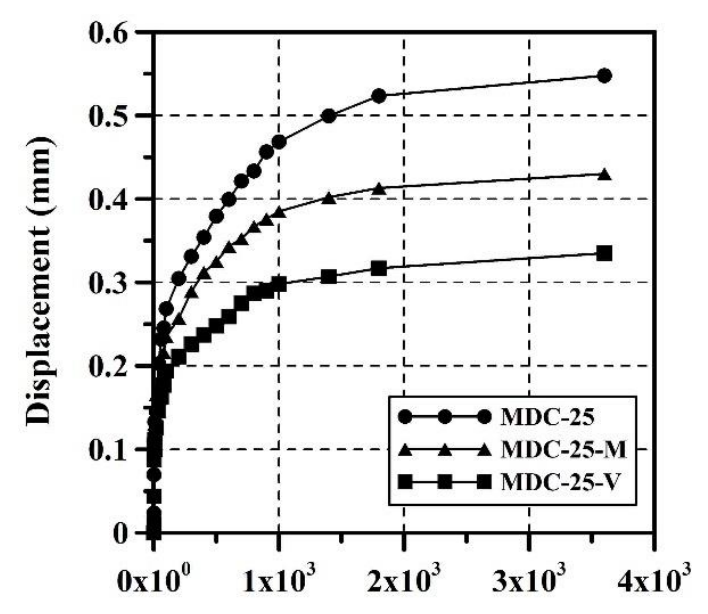

(b)

Number of cycles

Figure 7. Permanent displacement: (a) MDC-19, MDC-19-M, and MDC-19-V; (b) MDC-25, MDC-25-M, and MDC-25-V.

\subsection{Fatigue Test}

The results of fatigue tests are shown in Figure 8. An increase in fatigue resistance was observed in both gradations when NA was replaced with RCA according to volume and modified asphalt was used. This occurs because, generally, under stress-controlled conditions, the fatigue resistance of mixes increases with the increase in stiffness $[52,77,87,88]$.

Other behavior was obtained when NA was replaced with RCA according to mass. The fatigue resistance of the MDC-19 control mix was similar to that of MDC-19-M. Regarding MDC-25, replacing NA with RCA according to mass reduced its fatigue life. The greater quantity of RCA particles to be coated with asphalt and the greater porosity and reduction of VFA could have influenced this response. 


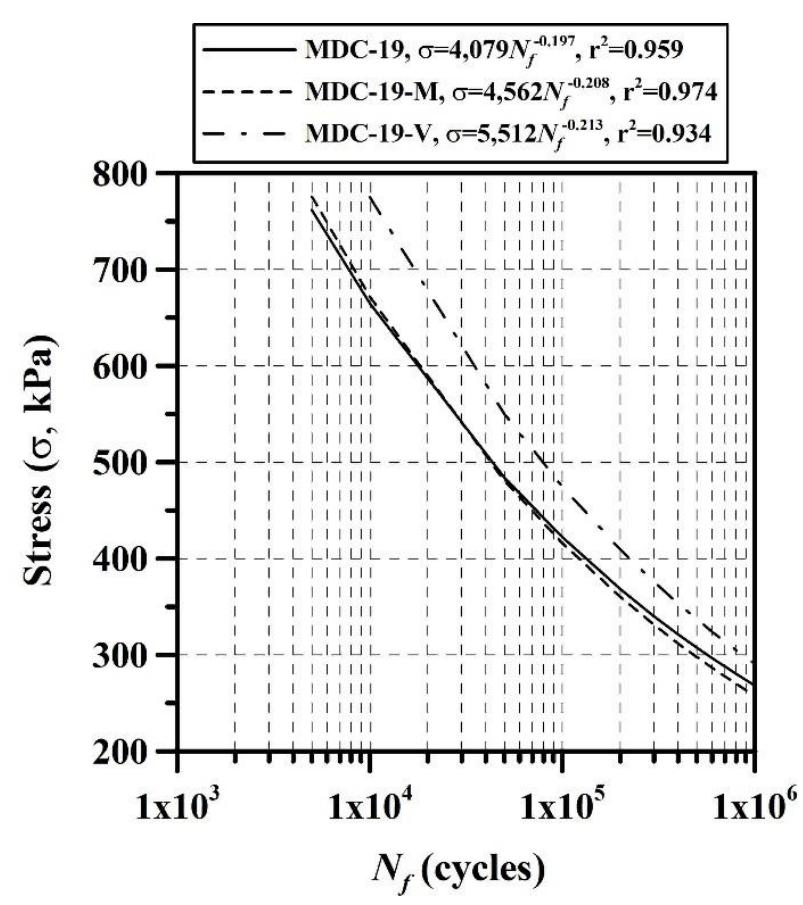

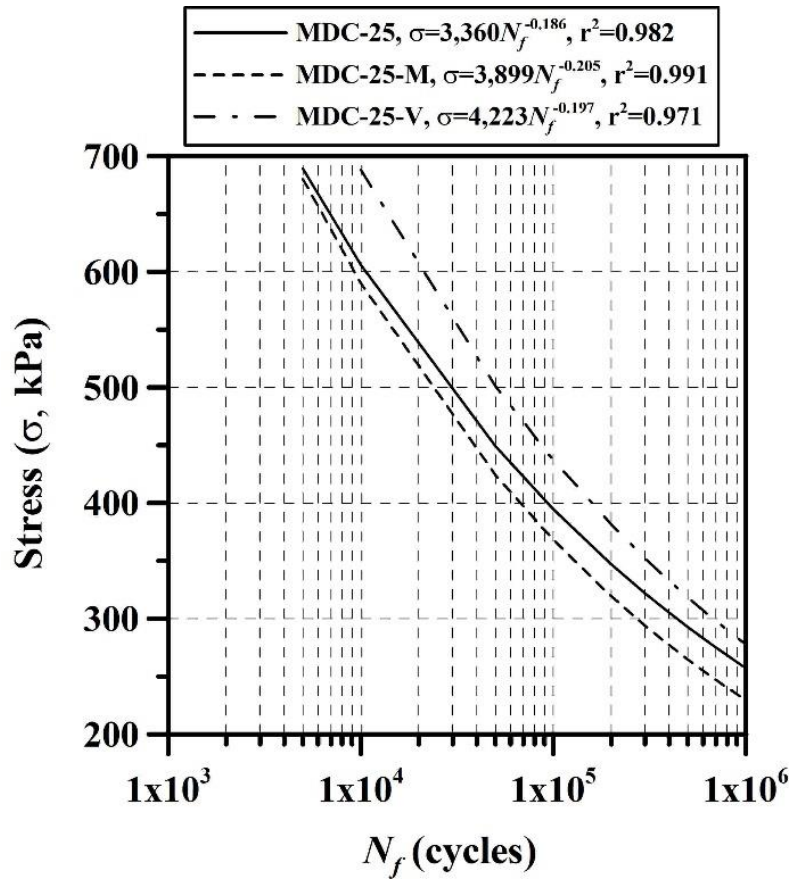

Figure 8. Fatigue curves: (a) MDC-19, MDC-19-M, and MDC-19-V; (b) MDC-25, MDC-25-M, and MDC-25-V.

\subsection{Indirect Tensile Strength and Cantabro Tests}

The results of the ITS and Cantabro tests are shown in Tables 5 and 6, respectively. Based on the ANOVA test, a notable reduction in the ITS-U, ITS-C, TSR, and ML parameters was observed when, in both gradations, the NA was replaced with RCA by mass and modified asphalt was used. The above is an indicator of loss of adherence, moisture damage resistance, and wear abrasion resistance. This was mainly due to the lower resistance to abrasive wear and crushing that RCA particles underwent. Additionally, gilsonite increased the viscosity of the modified asphalt binder, which could affect the adhesion between asphalt binder and aggregate. Despite this, both mixes of MDC-19-M and MDC-25-M presented TSR values that were superior to the minimum (80\%) requirements of the [74] standard.

Table 5. Indirect tensile strength (ITS) test results.

\begin{tabular}{ccccccc}
\hline Parameter & MDC-19 & MDC-19-M & MDC-19-V & MDC-25 & MDC-25-M & MDC-25-V \\
\hline $\begin{array}{c}\text { ITS-U } \\
(\mathrm{kPa})\end{array}$ & 1070.6 & 1026.7 & 1110.2 & 1111.4 & 1015.6 & 1151.9 \\
ITS-C & 967.8 & 849.2 & 1002.3 & 958.9 & 827.7 & 1002.3 \\
$(\mathrm{kPa})$ & 90.4 & 82.7 & 90.3 & 86.3 & 81.5 & 87.0 \\
TSR $(\%)$ & & & &
\end{tabular}

Table 6. Cantabro test results.

\begin{tabular}{cccccc}
\hline \multicolumn{7}{c}{ Mass Loss-ML (\%) at 500 Revolutions } \\
\hline MDC-19 & MDC-19-M & MDC-19-V & MDC-25 & MDC-25-M & MDC-25-V \\
\hline 8.82 & 9.21 & 8.66 & 9.87 & 11.10 & 9.93 \\
\hline
\end{tabular}

On the other hand, if replacement was carried out by volume, both ITS-U and ITS-C underwent statistically significant increases with relation to the control mixes (based on the ANOVA test). However, the TSR was similar, just like the ML. According to volume replacement, less RCA particles were introduced (compared with mass replacement), which could contribute to improving resistance in both tests. 


\section{Summary and Conclusions}

Based on the results obtained, the following conclusions are drawn.

Just as was shown in the background information, gilsonite increases asphalt's stiffness, and RCA presents particles with a greater absorption and lower mechanical resistance in comparison with those of NA.

Replacing a mass of $21 \%$ (MDC-19) and 24\% (MDC-25) for the coarse fraction of NA with RCA and using asphalt cement (AC 60-70) modified with gilsonite is not advisable, given that (i) it increases the asphalt binder content and porosity of mixes; (ii) the asphalt mix design allows for their use in roadways with low traffic volumes; (iii) it reduces resistance under a monotonic load (reduces S, S/F, ITS-U, and ITS-C parameters); (iv) reduces moisture damage resistance (reduces TSR) and abrasion resistance (increases ML); and (v) regarding MDC-19 gradation, it does not generate changes in fatigue resistance, but in MDC-25 it tends to reduce it. Despite the above, it could help to increase permanent deformation resistance in hot temperature climates and TSR values are coherent to the minimum values required by the standard.

Contrary to the above, replacing NA particles with RCA according volume and using modified asphalt could generate the following benefits: (i) it increases asphalt mix resistance under monotonic and cyclic loads (increases S, S/F, ITS-U, ITS-C, and RM parameters, as well as permanent deformation resistance and fatigue resistance under stress-controlled conditions), without increasing the asphalt binder content; (ii) the mix design allows for its use in roadways with any level of traffic; and (iii) in comparison with control mixes, it maintains its moisture damage resistance and abrasion resistance.

The previously described benefits of MDC-19-V and MDC-25-V mixes can be recommended for comprising the thick asphalt layers (greater than 4 inches) in hot temperature climate pavements. However, in low temperature climates and thin asphalt layers (less than 2 inches), the high stiffness of these mixes can cause fatigue cracking.

Author Contributions: Conceptualization, H.A.R.-Q., C.A.Z.-M., and D.A.Z.-A. methodology, H.A.R.Q. and C.A.Z.-M.; validation and formal analysis, D.A.Z.-A.; H.A.R.-Q.; and C.A.Z.-M.; resources, D.A.Z.-A., H.A.R.-Q., and C.A.Z.-M.; writing-original draft preparation, H.A.R.-Q. and C.A.Z.-M.; writing-review and editing, D.A.Z.-A. and H.A.R.-Q.; funding acquisition, D.A.Z.-A. All authors have read and agreed to the published version of the manuscript.

Funding: This research was funded by Centro de Investigaciones-Escuela de Ingenieros Militares (ESING), budget item A-02-02-02-008-001, Ejército Nacional de Colombia.

Institutional Review Board Statement: Not applicable.

Informed Consent Statement: Not applicable.

Data Availability Statement: Not applicable.

Conflicts of Interest: The authors declare no conflict of interest. The funders had no role in the design of the study; in the collection, analyses, or interpretation of data; in the writing of the manuscript; or in the decision to publish the results.

\section{References}

1. Ren, S.; Liang, M.; Fan, W.; Zhang, Y.; Qian, C.; He, Y.; Shi, J. Investigating the effects of SBR on the properties of gilsonite modified Asphalt. Constr. Build. Mater. 2018, 190, 1103-1116. [CrossRef]

2. Sobhi, S.; Yousefi, A.; Behnood, A. The effects of gilsonite and Sasobit on the mechanical properties and durability of asphalt mixtures. Constr. Build. Mater. 2020, 238, 117676. [CrossRef]

3. Liu, J.; Li, P. Experimental study on gilsonite-modified asphalt. In Proceedings of the Airfield and Highway Pavements 2008, Bellevue, WA, USA, 15-18 October 2008.

4. Nciri, N.; Song, S.; Kim, N.; Cho, N. Chemical characterization of gilsonite bitumen. J. Pet. Environ. Biotechnol. 2014, 5, 1-10.

5. Babagoli, R.; Hasaninia, M.; Namazi, N.M. Laboratory evaluation of the effect of gilsonite on the performance of stone matrix asphalt mixtures. Road Mater. Pavement Des. 2015, 16, 889-906. [CrossRef]

6. Davis, N., II; Tooman, C.E. New laboratory tests evaluate the effectiveness of gilsonite resin as a borehole stabilizer. SPE Drilling Eng. 1989, 4, 47-56. [CrossRef] 
7. Pakdaman, E.; Osfouri, S.; Azin, R.; Niknam, K.; Roohi, A. Synthesis and characterization of hydrophilic gilsonite fine particles for improving water-based drilling mud properties. J. Dispers. Sci. Technol. 2020, 41, 1633-1642. [CrossRef]

8. Wong, C.; Michael, K. The Effect of Gilsonite-Modified Asphalt on Hot Mix Asphaltic Concrete Mixes Used in District 12, Houston, Texas. Report No. DHT-22; Departmental Information Exchange, State Department of Highways and Public Transportation: Austin, TX, USA, 1990; p. 16.

9. Ameri, M.; Mansourian, A.; Sheikhmotevali, A.H. Investigating effects of ethylene vinyl acetate and gilsonite modifiers upon performance of base bitumen using Superpave tests methodology. Constr. Build. Mater. 2012, 36, 1001-1107. [CrossRef]

10. Li, K.; Vasiliu, M.; McAlpin, C.R.; Yang, Y.; Dixon, D.A.; Voorhees, K.J.; Batzle, M.; Liberatore, M.W.; Herring, A.M. Further insights into the structure and chemistry of the Gilsonite asphaltene from a combined theoretical and experimental approach. Fuel 2015, 157, 16-20. [CrossRef]

11. Vélez Herrera, J.S.; Restrepo, S.V.; Giraldo Vasquez, D. Mechanical and rheometric properties of gilsonite/carbon black/natural rubber compounds cured using conventional and efficient vulcanization systems. Polym. Test. 2016, 56, 1-9. [CrossRef]

12. Fang, Z.; Guang-you, Z.; Zhi-qiang, C.; Qiu-li, Z.; Quan, S. Molecular composition of vanadyl porphyrins in the gilsonite. J. Fuel Chem. Technol. 2020, 48, 562-567.

13. Sun, D. A Study on Xinjiang asphaltite as an asphalt modifier. Part II: Rheological evaluation of modified asphalt binders. Petrol. Sci. Tech. 2014, 32, 2059-2067. [CrossRef]

14. Sun, D. A Study on Xinjiang Asphaltite as an Asphalt Modifier. Part I: Composition, structure, and thermal behavior. Petrol. Sci. Tech. 2012, 30, 307-315. [CrossRef]

15. Esfeh, H.K.; Ghanavati, B.; GhaleGolabi, T. Properties of modified bitumen obtained from natural bitumen by adding pyrolysis fuel oil. Int. J. Chem. Eng. Appl. 2011, 2, 168-172. [CrossRef]

16. Widyatmoko, I.; Elliott, R. Characteristics of elastomeric and plastomeric binders in contact with natural asphalts. Constr. Build. Mater. 2008, 22, 239-249. [CrossRef]

17. Anderson, D.; Maurer, D.; Ramirez, T.; Christensen, D.; Marasteanu, M.; Mehta, Y. Field performance of modified asphalt binders evaluated with Superpave test methods: I-80 test project. Transport. Res. Rec. 1999, 1661, 60-68. [CrossRef]

18. Aflaki, S.; Tabatabaee, N. Proposals for modification of Iranian bitumen to meet the climatic requirements of Iran. Constr. Build. Mater. 2009, 23, 2141-2150. [CrossRef]

19. Cholewińska, M.; Iwański, M. Modification of petroleum road bitumen 50/70 with natural asphalt Gilsonite. Struct. Environ. 2011, 3, 5-10.

20. Kök, B.V.; Yilmaz, M.; Guler, M. Evaluation of high temperature performance of SBS + Gilsonite modified binder. Fuel 2011, 90, 3093-3099. [CrossRef]

21. Guo, Y.; Jiang, J.; Liu, W. Properties of Natural Bitumen Gilsonite Modified Bitumen. In Proceedings of the Fifth International Conference on Transportation Engineering, ASCE, Dailan, China, 26-27 September 2015.

22. Rondón-Quintana, H.A.; Noguera, J.A.; Urazán, C.F. Behavior of gilsonite-modified hot mix asphalt by wet and dry processes. J. Mater. Civ. Eng. 2016, 28, 04015114. [CrossRef]

23. Li, R.; Karki, P.; Hao, P.; Bhasin, A. Rheological and low temperature properties of asphalt composites containing rock asphalts. Constr. Build. Mater. 2015, 96, 47-54. [CrossRef]

24. Jahanian, H.R.; Shafabakhsh, G.; Divandari, H. Performance evaluation of hotmix asphalt (HMA) containing bitumen modified with gilsonite. Constr. Build. Mater. 2017, 131, 156-164. [CrossRef]

25. Tang, N.; Huang, W.; Zheng, M.; Hu, J. Investigation of Gilsonite-, polyphosphoric acid- and styrene-butadiene-styrene-modified asphalt binder using the multiple stress creep and recovery test. Road Mater. Pavement Des. 2017, 18, 1084-1097. [CrossRef]

26. Ameri, M.; Mirzaiyan, D.; Amini, A. Rutting Resistance and fatigue behavior of gilsonite-modified asphalt binders. J. Mater. Civ. Eng. 2018, 30, 04018292. [CrossRef]

27. Mirzaiyan, D.; Ameri, M.; Amini, A.; Sabouri, M.; Norouzi, A. Evaluation of the performance and temperature susceptibility of gilsonite and SBS-modified asphalt binders. Constr. Build. Mater. 2019, 207, 679-692. [CrossRef]

28. Rondón-Quintana, H.A.; Zafra, C.; Chavez, S. Performance characteristics and mechanical resistance of a hot mix asphalt using gilsonite and blast furnace slag. Sci. Rev. Eng. Environ. Sci. 2019, 28, 503-515. [CrossRef]

29. Gopinath, P.; Kumar, C.N. Performance evaluation of HMAC mixes produced with gilsonite modified bitumen for heavily trafficked roads. Mater. Today Proc. 2021, 43, 941-946. [CrossRef]

30. Nasrekani, A.A.; Naderi, K.; Nakhaei, M.; Mahmoodinia, N. High-temperature performance of gilsonite-modified asphalt binder and asphalt concrete. Petrol. Sci. Technol. 2016, 34, 1783-1789. [CrossRef]

31. Ameli, A.; Pakshir, A.H.; Babagoli, R.; Habibpour, A.; Norouzi, N.; Davoudinezhad, S. The effects of gilsonite and crumb rubber on moisture damage resistance of stone matrix asphalt mixtures. Constr. Build. Mater. 2021, 274, 122052. [CrossRef]

32. Ameri, M.; Mansourian, A.; Ashani, S.S.; Yadollahi, G. Technical study on the Iranian Gilsonite as an additive for modification of asphalt binders used in pavement construction. Constr. Build. Mater. 2011, 25, 1379-1387. [CrossRef]

33. Zhang, J.; Wang, J.; Wu, Y.; Sun, W.; Wang, Y. Investigation on thermo-rheological properties and stability of SBR modified asphalts containing palygorskite clay. J. Appl. Polym. Sci. 2009, 113, 2524-2535. [CrossRef]

34. Zhong, K.; Yang, X.; Luo, S. Performance evaluation of petroleum bitumen binders and mixtures modified by natural rock asphalt from Xinjiang China. Constr. Build. Mater. 2017, 154, 623-631. [CrossRef] 
35. Shi, X.; Cai, L.; Xu, W.; Fan, J.; Wang, X. Effect of nano-silica and rock asphalt on rheological properties of modified bitumen. Constr. Build. Mater. 2018, 161, 705-714. [CrossRef]

36. Yilmaz, M.; Yamaç, Ö.E. Evaluation of Gilsonite and Styrene-Butadiene-Styrene composite usage in bitumen modification on the mechanical properties of hot mix asphalts. J. Mater. Civ. Eng. 2017, 29, 04017089. [CrossRef]

37. Ameli, A.; Babagoli, R.; Asadi, S.; Norouzi, N. Investigation of the performance properties of asphalt binders and mixtures modified by Crumb Rubber and Gilsonite. Constr. Build. Mater. 2021, 279, 122424. [CrossRef]

38. Ke, Z.; Dong-wei, C.; Qing-quan, L. Research on the rheologic characteristics of gilsonite modified bitumen. J. Highw. Transp. Res. Dev. 2008, 3, 20-24.

39. Abergel, T.; Dean, B.; Dulac, J. Towards a Zero-Emission, Efficient, and Resilient Buildings 375 and Construction Sector: Global Status Report 2017; United Nations Environment and International 376 Energy Agency: Paris, France, 2017; p. 43.

40. Ghaffar, S.H.; Burman, M.; Braimah, N. Pathways to circular construction: An integrated management of construction and demolition waste for resource recovery. J. Clean. Prod. 2020, 244, 118710. [CrossRef]

41. Hasan, U.; Whyte, A.; Al Jassmi, H. Life cycle assessment of roadworks in United Arab Emirates: Recycled construction waste, reclaimed asphalt pavement, warm-mix asphalt and blast furnace slag use against traditional approach. J. Clean. Prod. 2020, 257, 120531. [CrossRef]

42. Jin, R.; Chen, Q. Overview of concrete recycling legislation and practice in the United States. J. Constr. Eng. Mgmt. 2019, 145, 05019004. [CrossRef]

43. Giri, J.P.; Panda, M.; Sahoo, U.C. Performance of bituminous mixes containing emulsion-treated recycled concrete aggregates. J. Mater. Civ. Eng. 2018, 30, 04018052. [CrossRef]

44. Cho, Y.H.; Yun, T.; Kim, I.T.; Choi, N.R. The application of recycled concrete aggregate (RCA) for hot mix asphalt (HMA) base layer aggregate. KSCE J. Civ. Eng. 2011, 15, 473-478. [CrossRef]

45. Motter, J.S.; Miranda, L.F.; Bernucci, L.L. Performance of hot mix asphalt concrete produced with coarse recycled concrete aggregate. J. Mater. Civ. Eng. 2015, 27, 04015030. [CrossRef]

46. Kareem, A.I.; Nikraz, H.; Asadi, H. Application of double-coated recycled concrete aggregates for hot-mix asphalt. J. Mater. Civ. Eng. 2019, 31, 04019036. [CrossRef]

47. Monu, K.; Ransinchung, G.; Pandey, G.S.; Singh, S. Performance evaluation of recycled-concrete aggregates and reclaimed-asphalt pavements for foam-mix asphalt mixes. J. Mater. Civ. Eng. 2020, 32, 04020295. [CrossRef]

48. Sanchez-Cotte, E.H.; Fuentes, L.; Martinez-Arguelles, G.; Rondón-Quintana, H.A.; Walubita, L.F.; Cantero-Durango, J.M. Influence of recycled concrete aggregates from different sources in hot mix asphalt design. Constr. Build. Mater. 2020, 259, 120427. [CrossRef]

49. Alnedawi, A.; Rahman, M.A. Recycled concrete aggregate as alternative pavement materials: Experimental and parametric study. J. Transp. Eng. B Pavements 2021, 147, 04020076. [CrossRef]

50. Pasandín, A.R.; Pérez, I. Laboratory evaluation of hot-mix asphalt containing construction and demolition waste. Constr. Build. Mater. 2013, 43, 497-505. [CrossRef]

51. Fatemi, S.; Imaninasab, R. Performance evaluation of recycled asphalt mixtures by construction and demolition waste materials. Constr. Build. Mater. 2016, 120, 450-456. [CrossRef]

52. Muniz de Farias, M.; Quiñonez, F.; Rondón, H.A. Behavior of a hot-mix asphalt made with recycled concrete aggregate and crumb rubber. Can. J. Civ. Eng. 2019, 46, 544-551. [CrossRef]

53. Zou, G.; Sun, X.; Liu, X.; Zhang, J. Influence factors on using recycled concrete aggregate in foamed asphalt mixtures based on tensile strength and moisture resistance. Constr. Build. Mater. 2020, 265, 120363. [CrossRef]

54. Natarajan, B.M.; Kanavas, Z.; Sanger, M.; Rudolph, J.; Chen, J.; Edil, T.; Ginder-Vogel, M. Characterization of recycled concrete aggregate after eight years of field deployment. J. Mater. Civ. Eng. 2019, 31, 04019070. [CrossRef]

55. Tahmoorian, F.; Yeaman, J.; Mirzababaei, M. Comparisons of the resilient moduli of asphalt mixes containing recycled materials through empirical and experimental methods. J. Mater. Civ. Eng. 2020, 32, 04020255. [CrossRef]

56. Tan, X.; Li, W.; Zhao, M.; Tam, V.W.Y. Numerical Discrete-Element Method investigation on failure process of recycled aggregate concrete. J. Mater. Civ. Eng. 2019, 31, 04018353. [CrossRef]

57. Tahmoorian, F.; Samali, B. Laboratory investigations on the utilization of RCA in asphalt mixtures. Int. J. Pavement Res. Technol. 2018, 11, 627-638. [CrossRef]

58. Nwakaire, C.M.; Yap, S.P.; Onn, C.C.; Yuen, C.W.; Ibrahim, H.A. Utilisation of recycled concrete aggregates for sustainable highway pavement applications; a review. Constr. Build. Mater. 2020, 235, 117444. [CrossRef]

59. Mikhailenko, P.; Kakar, M.R.; Piao, Z.; Bueno, M.; Poulikakos, L. Incorporation of recycled concrete aggregate (RCA) fractions in semidense asphalt (SDA) pavements: Volumetrics, durability and mechanical properties. Constr. Build. Mater. 2020, 264, 120166. [CrossRef]

60. Pérez, I.; Toledano, M.; Galego, J.; Taibo, J. Mechanical properties of hot mix asphalt made with recycled aggregates from reclaimed construction and demolition debris. Mater. Construcción 2007, 57, 17-29.

61. Pérez, I.; Gallego, J.; Toledano, M.; Taibo, J. Asphalt mixtures with construction and demolition debris. Proc. Inst. Civil. Eng. Transp. 2010, 163, 165-174. [CrossRef]

62. Pérez, I.; Pasandin, A.R.; Medina, L. Hot mix asphalt using C\&D waste as coarse aggregates. Mater. Des. 2012, 36, 840-846.

63. Mills-Beale, J.; You, Z. The mechanical properties of asphalt mixtures with recycled concrete aggregates. Constr. Build. Mater. 2010, 24, 340-345. [CrossRef] 
64. Qasrawi, H.; Asi, I. Effect of bitumen grade on hot asphalt mixes properties prepared using recycled coarse concrete aggregate. Constr. Build. Mater. 2016, 121, 18-24. [CrossRef]

65. Galan, J.J.; Silva, L.M.; Pérez, I.; Pasandín, A.R. Mechanical behavior of hot-mix asphalt made with recycled concrete aggregates from construction and demolition waste: A design of experiments approach. Sustainability 2019, 11, 3730. [CrossRef]

66. Lee, C.-H.; Du, J.-C.; Shen, D.-H. Evaluation of pre-coated recycled concrete aggregate for hot mix asphalt. Constr. Build. Mater. 2012, 28, 66-71. [CrossRef]

67. Pasandín, A.R.; Pérez, I. Mechanical properties of hot-mix asphalt made with recycled concrete aggregates coated with bitumen emulsion. Constr. Build. Mater. 2014, 55, 350-358. [CrossRef]

68. Zhu, Y.G.; Kou, S.C.; Poon, C.S.; Dai, J.G.; Li, Q.Y. Influence of silane-based water repellent on the durability properties of recycled aggregate concrete. Cem. Concr. Compos. 2013, 35, 32-38. [CrossRef]

69. Singh, M.; Roy, A.B.; Waseem, S.; Singh, H. Feasibility and performance analysis of carbonated recycled aggregate concrete. Int. J. Sustain. Eng. 2020. [CrossRef]

70. Bastidas, J.G.; Rondón-Quintana, H.A.; Zafra, C. Study of hot mix asphalt containing recycled concrete aggregates that were mechanically treated with a Los Angeles machine. Int. J. Civ. Eng. Technol. 2019, 10, 226-243.

71. Upshaw, M.; Cai, C.S. Critical review of recycled aggregate concrete properties, improvements, and numerical models. J. Mater. Civ. Eng. 2020, 32, 03120005. [CrossRef]

72. Raman, J.; Ramasamy, V. Various treatment techniques involved to enhance the recycled coarse aggregate in concrete: A review. Mater. Today Proc. 2020. [CrossRef]

73. IDEAM-UNAL (Instituto de Hidrología, Meteorología y Estudios Ambientales-Universidad Nacional de Colombia). Variabilidad Climática y Cambio Climático en Colombia; IDEAM-UNAL: Bogotá, Colombia, 2018.

74. INVIAS-Instituto Nacional de Vías. Especificaciones Generales de Construcción de Carreteras; INVIAS-Instituto Nacional de Vías: Bogotá, Colombia, 2020.

75. Ríos-Ocampo, J.P.; Olaya-Morales, Y.; Rivera-León, G.J. Proyección de la demanda de materiales de construcción en Colombia por medio de análisis de flujos de materiales y dinámica de sistemas. Rev. Ing. 2017, 16, 75-95. [CrossRef]

76. Rondón, H.A.; Reyes, F.A. Pavimentos: Materiales, Construcción y Diseño [Pavements: Materials, Construction and Design], 1st ed.; ECOE: Bogotá, Colombia, 2015.

77. Djakfar, L.; Bowoputro, H.; Prawiro, B.; Tarigan, N. Performance of recycled porous hot mix asphalt with gilsonite additive. HPC Adv. Civ. Eng. 2015, 2015, 316719. [CrossRef]

78. Rondón-Quintana, H.A.; Chaves-Pabón, S.; Escobar, D.A. Behavior of a porous asphalt mixture modified with Gilsonite. Indian J Sci. Technol. 2018, 11, 131587. [CrossRef]

79. Rondón-Quintana, H.A.; Zafra, C.; Rodriguez, J.P. Behavior of a hot mix asphalt using gilsonite and recycled concrete aggregate. Int. J. Adv. Sci. Technol. 2020, 29, 9723-9733.

80. Rondón-Quintana, H.A.; Ruge, J.C.; Muniz de Farias, M. Behavior of a hot mix asphalt containing blast furnace slag as aggregate: Evaluation by mass and volume substitution. J. Mater. Civ. Eng. 2019, 31, 04018364. [CrossRef]

81. Rondón-Quintana, H.A.; Zafra-Mejía, C.A.; Ruge-Cárdenas, J.C. Use of recycled concrete aggregate as a substitute of a natural aggregate by mass and volume within an asphalt concrete base. Int. J. Adv. Sci. Technol. 2020, 29, 10845-10850.

82. Delgado, M.G.; Sánchez, J.A.; Rondón-Quintana, H.A.; Fernández, W.D.; Reyes, F.A. Influence of four non-conventional additives on the physical, rheological and thermal properties of an asphalt. Ing. Investig. 2018, 32, 18-26. [CrossRef]

83. Shenoy, A.V. Determination of the temperature for mixing aggregates with polymer-modified asphalt. Int. J. Pavement Eng. 2001, 2, 33-47. [CrossRef]

84. West, R.C.; Watson, D.E.; Turner, P.A.; Casola, J.R. Mixing and Compaction Temperatures of Asphalt Binders in Hot-Mix Asphalt. NCHRP Rep. 648; Transportation Research Board: Washington, DC, USA, 2010; p. 156.

85. Cox, B.C.; Smith, B.T.; Howard, I.L.; James, R.S. State of knowledge for Cantabro testing of dense graded asphalt. J. Mater. Civ. Eng. 2017, 29, 04017174. [CrossRef]

86. Doyle, J.D.; Howard, I.L. Characterization of dense-graded asphalt with the Cantabro test. J. Test. Eval. 2016, 44, 77-88. [CrossRef]

87. Rondón-Quintana, H.A.; Ruge-Cárdenas, J.C.; Bastidas-Martínez, J.G.; Velandia-Castelblanco, M.Y.; Muniz De Farias, M. Use of thermally treated bentonite as filler in hot mix asphalt. J. Mater. Civil. Eng. 2020, 32, 1-10. [CrossRef]

88. Bharath, G.; Reddy, K.S.; Tandon, V.; Reddy, M.A. Aggregate gradation effect on the fatigue performance of recycled asphalt mixtures. Road Mater. Pavement Des. 2021, 22, 165-184. [CrossRef] 